\title{
The Effect of Finger Painting Media Implementation on Audio Fine Motor Skills
}

\author{
PASCALIAN HADI PRADANA \\ Program Studi Pendidikan Guru Pendidikan Anak Usia Dini, IKIP PGRI Jember, Indonesia. \\ Email: Pascalian10@gmail.com \\ Article Received: 30 January $2019 \quad$ Published Article: 02 May 2020 \\ DOI: https://doi.org/10.29313/ga:jpaud.v3i2.5616
}

\begin{abstract}
This research aims to determine the effect of Finger Painting Learning Media on the development of fine motor skills in early childhood. The design carried out by researchers in this research uses a quantitative approach to the type of Pre-Experiment, using an impure experimental model (one-shot case study) as an experiment is carried out there is no comparison of groups and also without preliminary tests. For this research data study, the independent variable (variable $\mathrm{x}$ ) is the finger Painting media application, and the dependent variable (variable $y$ ) is fine motor skills. The analysis used is Chi-Square, with a significance level of $1 \%$, obtained then $X_{\text {table }}=3,841 X_{\text {count }}$ value $=6,12$. Thus the value of $X_{\text {count }}>X_{\text {table }}(6.12>$ 3.841) means rejecting the null hypothesis $(\mathrm{HO})$, and the working hypothesis $(\mathrm{Ha})$ is accepted. Thus, There Is The Effect Of The Application Of Finger Painting Learning Media On The Improvement Of Fine Motor Ability In Early Childhood.
\end{abstract}

Keywords: Fine Motorbike; Finger Painting.

\begin{abstract}
Abstrak
Riset ini bertujuan agar melihat adanya Pengaruh Penerapan Media Pembelajaran Finger Painting Terhadap Pengembangan Kemampuan Motorik Halus Anak usia dini. Rancangan yang dilakukan penulis dalam riset ini memakai pendekatan kuantitatif dengan tipe PreExperiment, dengan menggunakan model eksperimen tidak murni (one-shot case study) sebagaimana suatu eksprimen dilakukan tidak ada pebandingan kelompok dan tidak ada pree test. Untuk Pengkajian data riset ini, yang menjadi variabel $x$ (variabel bebasnya) yaitu penerapan media Finger Painting, beserta variabel y (variabel terikatnya) yaitu kemampuan motorik halus. Analisis yang digunakan yaitu Chi Kuadrat, dengan taraf signifikan 1\%, didapat maka $X_{\text {tabel }}=3,841$ nilai $X_{\text {hitung }}=6,12$. Dengan demikian nilai $X_{\text {hitung }}>X_{\text {tabel }}(6,12>3,841)$ berarti, menolak hipotesis nihil $\left(H_{0}\right)$ beserta hipotesis kerja $\left(H_{a}\right)$ diterima. Sehingga, Ada Pengaruh Penerapan Media Pembelajaran Finger Painting Terhadap Peningkatan Kemampuan Motorik Halus Anak Usia Dini.
\end{abstract}

Kata Kunci: Motorik Halus; Finger Painting. 


\section{INTRODUCTION}

According to (Mulyasa 2011, p. 121), learning success is students' success in forming competencies and achieving goals and teachers' success in guiding children during the learning process. The planning of learning objectives is achieved, along with being guided by the curriculum being used today. Therefore, in essence, the success of curriculum implementation is the success of learning. In school learning, the essential role of teachers and is very influential in early childhood education. So the teacher is the main character who is responsible for learning success. The teacher's role and role in learning include several things: a facilitator, demonstrator, motivator, inspiration, the trigger of learning, learning engineer, and evaluator.

According to (Subandowo and Suryaman, 2015, p. 15) early childhood education is one form of education that focuses on laying the foundation for growth and development, namely: moral and religious development, physical (fine/gross motor), cognitive intelligence, socio-emotional, language, and communication. Children at an early age are both individualists and part of social beings. An individualist figure is a creature that accentuates personal/individual interests and needs that are seen from how to realize their desires by crying, seizing, and wanting to win by themselves. As social creatures, each individual will interact and socialize with fellow Early Childhood (AUD) and adults. We can see if they are playing with friends with adult guidance so that children feel comfortable, happy, and cheerful. Educating and instilling moral values should be done since Early Childhood (AUD) because it is easier to develop children's brain cells at a very young age. If one educates children, it will be fatal and can make brain cells' development do not develop optimally, and vice versa. If we educate children and instill moral values from an early age, they will develop optimally and be more independent. Every child has its uniqueness and unique characteristics and has different physical characteristics/characteristics.

The varying levels of early childhood development (AUD) will eventually have implications for specific future characteristics. Fundamental development will be experienced in every development process in Early Childhood (AUD), meaning that development through experience from the earliest possible age will make a contribution that will always be inherent in the child's mind until the long term so that it dramatically affects the excellent development of the child later. Some potentials are possessed by each individual, potentials both in terms of socioemotional and the child's physicalbiological potential. Growth and development have the same meaning as behavior change. The behavior changes that are intended are behavioral changes related to not one aspect but include the whole aspect to be a change in behavior from learning. Learning is not said to be complete if it results in changes in only one or two aspects. (Surya, 2014, p. 125).

Children in their golden age that is up to 7 years of age at that time the child is excellent in its development until it is optimal. Therefore, children as early as possible need to be implanted traits that can foster self-confidence independently. Children always do everything even though it endangers them because children have higher curiosity, so curiosity and curiosity are more significant in their development, even though what is done is dangerous.

Educating children early is very important and exemplary because it is a foundation in the child's growth and development. Children need guidance, stimulation, and coaching as early as possible so that they can enhance growth and development both in terms of physical, mental, and more to optimize the abilities they have, as physical and mental and according to (Suyadi 2010, p. 69), comparing subtle motor movements and gross motor movements. In other words, when a child is preschool-age, he will experience a significant change in his motor movements.

The motor is divided into two groups, including gross motor and fine motor. To develop fine motor skills, in education, especially related to Early Childhood, there needs to be an activity including dancing, sticking, painting, drawing, and other activities that familiarize the muscles in facilitating and smoothing the motor development of children. At the age of children - children should need an activity that can make children happy, and these activities must be more creative and innovative so that they can also develop fine motor 
skills. Among them to develop brain and fine motor skills in children are by playing with finger painting activities. The Institute of RA AL BADRI Kalisat Jember urgently needs learning about improving fine motor skills. By applying finger painting activities, children's ability to improve fine motor skills will increase as expected. Because the institution is many demands from student guardians, children can write neatly, coloring perfectly. To train a child's fine motor skills and make children feel attracted, happy and comfortable, playing finger painting activities is the right solution because this painting activity allows children to move their fingers freely, can hold their emotions, children are not afraid to get dirty, foster truest self, independent, imagination and curiosity will emerge if the child already feels interested in finger painting activities. By seeing a variety of colors and mixing colors that need to be used to do finger painting activities, the child feels compelled to do it using fingers or palms. Therefore, the writer is very interested in finger painting activities because it can make the child is fine motor muscles and the intelligence of the child's brain will be more developed.

According to (Aisha 2014, p. 7.11), finger painting is a valuable drawing and spontaneous expression. Finger painting activities are not only to prioritize fine motor development but also to play activities so that children feel happy and increase their psychological development. Children are interested in doing finger painting activities by their own volition, and without coercion, it is necessary to play a tool or media. Some ways of finger painting: First, mix one color with a different color; second, combining one color with a different color; third, affix in order with new shapes, new colors, and sticking using other materials. Children can mix their colors according to the desired color to become happy doing finger painting activities.

According to Pamadhi, (Sukardi, 2015, p. 3.2), painting is a learning activity by playing shapes and colors and lines arranged in a medium, be it paper, fabric, canvas, or a complete wall. Finger painting with the hope of stimulating creative sensitivity in drawing skills. Finger painting activities can be given at TPA, KB, and TK. This activity begins by preparing drawing paper and finger paint dough with a minimum of three colors, namely red, yellow, and blue. The teacher practices and exemplifies the child and allows the child to express himself through hand painting. For example, it is collecting paper with colors according to the desired shape. Paper is folded in and pressed. The paper is pressed using nails or other objects that are not too pointed, the paper is opened and will form a good abstract; the paper is aired to dry.

The application of finger painting activities implemented on children is a very suitable activity, other than as a playground, to improve the child's fine motor skills. Because developing fine motor skills will increase the harmonization of body movements that will link nerves and muscles in more detail. Combined nerves with groups like this help develop subtle motor movements in children, such as coloring, writing, and squeezing paper.

Monitoring early childhood growth and motor movement development is needed by educators/teachers who understand every detail of child development, know the problems and stimulation steps for children to develop according to their age of growth by using media, games, and external and internal stimuli the child. Early age, while most educators/teachers in RA AL BADRI are academic competencies who are high school graduates who have not been equipped with knowledge about the growth and development of young children.

Based on the description that has been discussed, the authors conclude that the application of finger painting activities that can stimulate the ability of fine motor development in children from an early age. With finger painting children can do by moving their fingers in making a shape by their wishes. Also, the media can improve children's creative abilities. Through the application of finger painting, children can imagine, children are not afraid to get dirty in doing activities and stimulate children to write neater. Finger painting is an activity that can be fun and also stimulate the interests and talents of children to develop fine motor skills and can relax the nerves and muscles of the hands as well as the fingers of the child. 


\section{RESEARCH METHODOLOGY}

In this research, the author uses a quantitative research approach design through the type of experimental research (pre-experiment), using an impure experimental model (one-shot case study), where the writer/researcher conducts a data retrieval (treatment) in his research that only one time can be interpreted there is influence. (Arikunto, 2013, p. 124). In connection with this research, the researcher intends to determine whether there is an influence of finger painting media on the development of fine motor skills in AUD in RA Al Badri Kalisat, Jember Regency.

In collecting data in int research used Observation and Documentation methods. To analyze the data in this research, statistical methods are used. This method's use is based on the acquisition of data from the results of research in the form of quantitative data that is data analysis used to test hypotheses and answer the problem formulation in this research. To conclude, it is necessary to analyze the data as a process for making decisions in data analysis. Classification of data using parametric statistics requires that the variable data be analyzed need to be distributed normally. The author applies a statistical method of data analysis by expressing chi-squared, the formula of which is as follows:

$x^{2}=\sum \frac{\left(f_{0-} f_{h}\right)^{2}}{f_{h}}$

Information :

$x^{2}=$ Chi-square of the significant frequency observed

$f_{0}=$ Frequency obtained based on data

$f_{h} \quad=$ Frequency expected. (Arikunto, 2013: 333)

Informant or respondent in detecting both (B) and less $(\mathrm{K})$ provisions in finger painting application by finding the mean (mean) with the formula $\mathrm{M}=\frac{\sum X}{N}$, then the value obtained from the average of 510/30 $=17$, therefore the authors set an average standard of 17 . If the price of variable $X$ is greater than 17 , it is said to be useful, but less than 17 is said to be less. Likewise in detecting both (B) and less (K) conditions in fine motor skills by finding the mean (mean) with the formula $\mathrm{M}=\frac{\sum X}{N}$, the values obtained from the average of $511 / 30=17.03$. Therefore the authors set the average standard in fine motor skills that are 17.03. If the value of variable $Y$ is greater than 17 , it is said to be useful, but if less than 17 , it is said to be less.

To calculate the effect of finger painting (variable $\mathrm{X}$ ) on fine motor skills (variable $\mathrm{Y}$ ) Early Childhood at RA Al Badri, Kalisat District, Jember Regency using the Chi-Square formula.

To make it easier to calculate with the ChiSquare formula, the following table is needed:

Table 1. Calculate using the Chi-Square formula

\begin{tabular}{|c|c|c|c|c|c|c|c|c|}
\hline \multirow[t]{2}{*}{ No } & \multirow{2}{*}{$\begin{array}{l}\text { Finger } \\
(X) \\
\text { Skor }\end{array}$} & \multirow{2}{*}{$\begin{array}{l}\text { Painting } \\
\text { Categor } \\
\text { y }\end{array}$} & \multicolumn{2}{|c|}{$\begin{array}{l}\text { Fine Motor } \\
(\mathrm{Y})\end{array}$} & \multicolumn{4}{|c|}{$\begin{array}{l}\text { Relationship } \\
\text { between } X \text { and } Y\end{array}$} \\
\hline & & & $\begin{array}{l}\text { Sk } \\
\text { or }\end{array}$ & $\begin{array}{l}\text { Categor } \\
\text { yi }\end{array}$ & $\begin{array}{l}\text { B } \\
\text { B }\end{array}$ & $\begin{array}{l}\text { B } \\
K\end{array}$ & $\begin{array}{l}K \\
B\end{array}$ & $\begin{array}{l}K \\
K\end{array}$ \\
\hline 1 & 17 & $B$ & 16 & $\mathrm{~K}$ & & $\begin{array}{l}\mathrm{B} \\
\mathrm{K}\end{array}$ & & \\
\hline 2 & 15 & $\mathrm{~K}$ & 12 & $\mathrm{~K}$ & & & & $\begin{array}{l}\mathrm{K} \\
\mathrm{K}\end{array}$ \\
\hline 3 & 20 & B & 20 & B & $\begin{array}{l}\mathrm{B} \\
\mathrm{B}\end{array}$ & & & \\
\hline 4 & 15 & $\mathrm{~K}$ & 14 & $\mathrm{~K}$ & & & & $\begin{array}{l}\mathrm{K} \\
\mathrm{K}\end{array}$ \\
\hline 5 & 18 & B & 17 & B & $\begin{array}{l}B \\
B\end{array}$ & & & \\
\hline 6 & 15 & $\mathrm{~K}$ & 15 & $\mathrm{~K}$ & & & & $\begin{array}{l}\mathrm{K} \\
\mathrm{K}\end{array}$ \\
\hline 7 & 18 & B & 18 & B & $\begin{array}{l}B \\
B\end{array}$ & & & \\
\hline 8 & 16 & $\mathrm{~K}$ & 18 & $B$ & & & $\begin{array}{l}K \\
B\end{array}$ & \\
\hline 9 & 19 & B & 16 & $\mathrm{~K}$ & & $\begin{array}{l}\mathrm{B} \\
\mathrm{K}\end{array}$ & & \\
\hline 10 & 15 & $\mathrm{~K}$ & 17 & B & & & $\begin{array}{l}\mathrm{K} \\
\mathrm{B}\end{array}$ & \\
\hline 11 & 12 & $\mathrm{~K}$ & 14 & $\mathrm{~K}$ & & & & $\begin{array}{l}\mathrm{K} \\
\mathrm{K}\end{array}$ \\
\hline 12 & 14 & $\mathrm{~K}$ & 18 & B & & & $\begin{array}{l}K \\
B\end{array}$ & \\
\hline 13 & 16 & $\mathrm{~K}$ & 17 & B & & & $\begin{array}{l}K \\
B\end{array}$ & \\
\hline 14 & 16 & $\mathrm{~K}$ & 17 & B & & & $\begin{array}{l}K \\
B\end{array}$ & \\
\hline 15 & 16 & $\mathrm{~K}$ & 15 & $\mathrm{~K}$ & & & & $\begin{array}{l}\mathrm{K} \\
\mathrm{K}\end{array}$ \\
\hline 16 & 18 & B & 17 & B & $\begin{array}{l}B \\
B\end{array}$ & & & \\
\hline 17 & 20 & B & 17 & B & $\begin{array}{l}B \\
B\end{array}$ & & & \\
\hline 18 & 20 & B & 17 & B & $\begin{array}{l}B \\
B\end{array}$ & & & \\
\hline 19 & 19 & $B$ & 20 & B & $\begin{array}{l}B \\
B\end{array}$ & & & \\
\hline 20 & 18 & B & 19 & B & $\begin{array}{l}B \\
B\end{array}$ & & & \\
\hline 21 & 17 & B & 18 & B & $\begin{array}{l}B \\
B\end{array}$ & & & \\
\hline 22 & 17 & B & 17 & B & $\begin{array}{l}B \\
B\end{array}$ & & & \\
\hline 23 & 17 & B & 17 & B & $\begin{array}{l}B \\
B\end{array}$ & & & \\
\hline 24 & 16 & $\mathrm{~K}$ & 16 & $\mathrm{~K}$ & & & & $\begin{array}{l}\mathrm{K} \\
\mathrm{K}\end{array}$ \\
\hline 25 & 16 & $\mathrm{~K}$ & 17 & B & & & $\begin{array}{l}\mathrm{K} \\
\mathrm{B}\end{array}$ & \\
\hline
\end{tabular}




\begin{tabular}{|c|c|c|c|c|c|c|c|}
\hline 26 & 17 & B & 19 & B & $\begin{array}{l}\text { B } \\
B\end{array}$ & & \\
\hline 27 & 20 & $B$ & 20 & $B$ & $\begin{array}{l}B \\
B\end{array}$ & & \\
\hline 28 & 16 & $\mathrm{~K}$ & 16 & $\mathrm{~K}$ & & & $\begin{array}{l}\mathrm{K} \\
\mathrm{K}\end{array}$ \\
\hline 29 & 20 & $B$ & 18 & $B$ & $\begin{array}{l}B \\
B\end{array}$ & & \\
\hline 30 & 17 & B & 19 & B & $\begin{array}{l}\text { B } \\
B\end{array}$ & & \\
\hline Jumlah & & & & & $\begin{array}{l}1 \\
5\end{array}$ & 2 & 7 \\
\hline
\end{tabular}

\begin{tabular}{ccc}
\hline Db & \multicolumn{2}{c}{ Significance Level } \\
\cline { 2 - 3 } & 5 & 1 \\
1 & 3.841 & 6.635 \\
2 & 5.991 & 9.210 \\
3 & 7.815 & 11.341 \\
4 & 9.488 & 13.277 \\
\hline 5 & 11,070 & 15,086 \\
\hline
\end{tabular}

$\mathrm{BB}=$ Good - Good

$$
\begin{aligned}
& \text { BK }=\text { Good }- \text { Poor } \\
& \text { KB }=\text { Poor }- \text { Good } \\
& \text { KK }=\text { Less - less }
\end{aligned}
$$

Table 2. Associations of variables $X$ and $Y$ variables The expected value (fh) and data in the table are as follows:

$f h=\underline{\text { Number of Frequencies } X \text { the number of Frequencies of a Column }}$

\begin{tabular}{|c|c|c|c|c|c|c|}
\hline $\begin{array}{c}\text { Varia } \\
\text { bel } \\
X\end{array}$ & $\begin{array}{c}\text { Variabel } \\
Y\end{array}$ & fo & $f h$ & fo-fh & $\begin{array}{l}\text { (fo- } \\
\text { fh) }\end{array}$ & $\frac{(f 0-f h)^{2}}{f h}$ \\
\hline \multirow[t]{2}{*}{ Good } & Good & 15 & $\begin{array}{c}11, \\
9\end{array}$ & 3,1 & 9,61 & 0,81 \\
\hline & Poor & 2 & 5,1 & $-3,1$ & 9,61 & 1,89 \\
\hline \multirow[t]{2}{*}{ Poor } & Good & 6 & 9,1 & $-3,1$ & 9,61 & 1,01 \\
\hline & Poor & 7 & 3,9 & 3,1 & 9,61 & 2,41 \\
\hline \multicolumn{2}{|c|}{ amount } & \multicolumn{2}{|c|}{3} & \multicolumn{2}{|c|}{ - } & $\begin{array}{c}6 \\
1 \\
2\end{array}$ \\
\hline
\end{tabular}

$$
\begin{aligned}
& f h(\mathrm{BB})=\frac{17 \times 21}{30}=11,9 \\
& f h(\mathrm{BK})=\frac{17 \times 9}{30}=5,1 \\
& f h(\mathrm{~KB})=\frac{13 \times 21}{30}=9,1 \\
& f h(\mathrm{KK})=\frac{13 \times 9}{30}=3,9
\end{aligned}
$$

Table 3. Work to Find Squares

From the table above, it can be seen that the Chi-Square value is 6.12. To clarify this value, it needs to be accompanied by the Chi-Squared table value with $\mathrm{db}$ and special error categories.

To determine also makes it easy to find a significant level of $X^{2}$ table, then first look for $\mathrm{db}$ values, and $\mathrm{db}$ values are related along with the addition of frequencies in each cell. In determining two samples, using the formula $\mathrm{db}=($ row -1$)$ (column-1) by using the calculation formula $\mathrm{db}$ will get the value:

$\mathrm{db}=$ (number of rows 1 ) (number of columns 1) $=(2-1)(2-1)=1 \times 1=1$.

Obtained $\mathrm{db}=1$ value with a significant level of using $5 \%$ is obtained so that $X$ table $=3,841 X$ value calculated $=6.12$. Thus the calculated $X$ value $>X$ table $(6.12>3.841)$ so that the null hypothesis will be rejected and accept the working hypothesis. Then there is the influence of the use of Finger Painting Media on AUD Fine Motor Skills at RA Al Badri Kalisat, Jember Regency. Next to determine the extent of the $\mathrm{db}=1$ value and the significance value using $5 \%$ is obtained so that $X$ table $=3.841$.

Table 4. Table of Chi-Square Values

\begin{tabular}{llll}
$\begin{array}{l}\text { Finger } \\
\text { Painting }(X)\end{array}$ & $\begin{array}{l}\text { Fine } \\
\text { Motor } \\
\text { (Y) }\end{array}$ & amount \\
& $\begin{array}{l}\text { Go } \\
\text { od }\end{array}$ & Poor \\
& 15 & 2 & 17 \\
Good & 6 & 7 & 13 \\
Poor & 21 & 9 & 30 \\
\hline amount & 21 &
\end{tabular}

\section{DISCUSSION}

Verification of the informants in this research uses the population method by using all or all children in group A to be informants/respondents, totaling 30 children used in this research. The scoring data uses finger painting learning media through observation method, which consists of 5 items as follows: 1) Spontaneous making pictures, 2) Not afraid of being dirty, 3) Developing imagination, 4) Knowing colors, 5) Creativity. The standard arrangement listed is based on the mean value of all respondents obtained using the formula: $\mathrm{M}=\frac{\sum X}{N}, \mathrm{M}=$ Mean, $\sum X=$ Total value, $\mathrm{N}=$ All respondents.

To find out both the criteria $(\mathrm{B})$ and less $(\mathrm{K})$ about the use of Finger Painting, the average (mean) can be 17 . So the researchers set to use the average value provisions with the following details: a) The Variable Value IX is greater than 16.5 is categorized as good (B), b) The value of Variable $X$ that is smaller than 16.5 is categorized as less $(K)$. 
Data on the scoring results of fine motor skills using the observation method using these 5 items, namely: 1) Eye and hand coordination, 2) Skillful hand movements, 3) Movement control, 4) Controlling emotions, 5) Confidence. In looking for good $(\mathrm{B})$ and less $(\mathrm{K})$ provisions regarding fine motor skills, so with a mean (mean), so that researchers set using the average value provisions with the provisions including a) Value of Variable $Y$ greater than 16.9 including the good group $(B), b)$ the level of Variable $Y$ which is smaller than 117.03 classified as less $(K)$.

After the main data is obtained, the next step is to calculate the effect of finger painting (variable $X$ ) on fine motor skills (variable $Y$ ) of the child using the Chi-Square formula. The data table uses the ChiSquare value of 6.12 . In providing clarification in obtaining this result, it is compared between the calculated Chi-Square table with $\mathrm{db}$ and the specific error provisions. Obtain the calculated price db used to make it easier to obtain significant provisions of $X^{2}$ tables. Along with $\mathrm{db}=1$ the $5 \%$ significance requirement is obtained $X$ table $=3.841$ value Xcount $=6.12$. Thus the value of Xcount $>$ Xtable $(6.12>3.841)$ rejects the submission of the null hypothesis and accepts the working hypothesis. Then, there was an Effect of the Application of Finger Painting Learning Media on Improving Children's Fine Motor Skills. Furthermore, to determine the extent of $\mathrm{db}=1$ with the provision of $5 \%$ significance, the price of $X^{2}$ table $=3.841$.

According to the results of opinions from research taken in journals relating to this research, including 1) Based on the research results (Handayani et al., 2018). These data show that the price of tcount $>$ from the table price, $(16.89>2.093)$. At a significant level of $5 \%(\propto=0.05)$ with $d k=n-1$. So the data shows that the group children's fine motor skills learned through finger painting have an average higher than the group learned without using finger painting. 2) Likewise, the results of research conducted by (Nunung et al., 2017) showed that the results of the univariate test showed a median score of 4.00 and a post-test of 6.00 , the results of the bivariate test obtained a $p$-value of $0.001(a<0.05)$ ), it can be concluded that there are significant differences in motor development of pre-school age children before and after finger painting activities.
The results of this research analysis concluded that there is an effect of the application of Finger Painting Learning Media on the Improvement of AUD Fine Motoric Capability. The acquisition of this data means that the theory that finger painting learning media is very influential in improving children's fine motor skills. In enhancing fine motor skills in early childhood education that is pleasing not only from the teacher's task but also in collaboration with parents and the surrounding environment.

Finger painting activities are very suitable given and implemented by children from an early age to train fine motor skills. This activity is carried out using the fingers directly touching the paint. Children without fear of getting dirty, but children feel happy and comfortable. The events listed are proportional to the data acquisition obtained that the calculated $X^{2}$ value $>X^{2}$ value of the table. The final results obtained reject the null hypothesis and accept the meaningful working hypothesis. The influence of finger painting learning media to increase the fine motor skills of AUD in RA Al Badri Kalisat Jember Regency. Starting from the description, the writer concludes that finger painting learning media is beneficial, practical, and significant. In this case, the teacher must always have to always educate and guide children in the use of finger painting learning media on fine motor skills even though the teacher's human resources (HR) is still not optimal enough.

\section{CONCLUSION}

Based on the acquisition of research that has been made, the authors conclude. There is an Effect of the Application of Finger Painting Media on Fine Motor Capabilities of Children 5-6 years old. With Db $=1$ and a significance level of $5 \%$ obtained, Xtable = $3.841 X$ value of 6.12 . Thus the value of $X$ count $>$ Xtable $(6.12>3.841)$ rejects the submission of the null hypothesis and accepts the working hypothesis.

Sourced from the conclusions that the author has examined, some suggestions are obtained as follows. 1) The role of teachers and parents should be more to optimize the media in enhancing children's growth and development. One of them is the application of Finger Painting Media that can optimize fine motor skills in children. 2) In the application of learning for children to be more creative and innovative, especially fun for children, 
Golden Age: Jurnal Pendidikan Anak Usia Dini, Volume 3 Nomor 2 (Desember 2019) ISSN 2549-8371 | E-ISSN 2580-5843

Pascalian Hadi Pradana / The Effect Of Finger Painting Media Implementation On Audio Fine Motor Skills

the application of finger painting learning media is

beneficial, practical, and significant.

\section{REFERENCES}

Aisyah, S. (2014). Development and Basic Concepts of Early Childhood Development. Open University Publisher.

Arikunto, S. (2013). Research Procedure: A Practice Approach (Revised Edition). In Jakarta: Rineka Cipta. https://doi.org/10.1017/CB0978110741532 4.004

Handayani, K. S. W., Drs. Ida Bagus Surya Manuaba, S.Pd., M. F., \& Luh Ayu Tirtayani, S.Psi., M. P. (2018). THE EFFECT OF FINGER PAINTING ON FINE MOTOR SKILLS OF EARLY AGE CHILDREN AGE B2 IN TK GANESHA SOUTH DENPASAR SOUTH 2017/2018. Undiksha Early Childhood Education Journal, 6 (1). https://doi.org/10.23887/paud.v6i1.15237

Mulyasa. (2011). Become a Professional Teacher. PT Youth Rosdakarya.

Nunung, N., Suryaningsih, C., \& Putra, B. D. A. (2017). The Influence of Finger Painting on the Development of Fine Motoric Preschoolers. Nursing, V (2), 65-73.

Subandowo and Suryaman. (2015). Education Policy. Wineka Media.

Sukardi, E. (2015). Children's Art Skills. Open University Publisher.

Surya, M. (2014). Teacher Psychology: Concepts and Applications. Alfabeta.

Suyadi (2010). PAUD Learning Psychology. PT Bintang Pustaka Abadi (BIPA). 